\title{
Safety and efficacy of botulinum toxin type-A preparations in cerebral palsy - an evidence-based review
}

\author{
Marcin Bonikowski ${ }^{1}$, Jarosław Sławek ${ }^{2}$ \\ ${ }^{1}$ Mazovian Neuropsychiatry Centre, Limited Liability Company, Neuro Rehabilitation Department, Movement Analysis Lab., Zagorze, Poland \\ ${ }^{2}$ Division of Neurological and Psychiatric Nursing, Faculty of Health Sciences, Medical University of Gdansk, Poland; \\ Department of Neurology and Stroke, St. Adalbert Hospital, Gdansk, Poland
}

\begin{abstract}
The introduction of botulinum toxin more than 25 years ago for the management of paediatric lower and upper limb hypertonia has been a major advance. BoNT-A as a part of multimodal treatment supports motor development and improves function disturbed by spasticity or hypertonia.

The aim of this paper was to compare the efficacy and safety of three major BoNT-A preparations present on the market: abo-, inco-, and onaobotulinumtoxinA in the treatment of children with cerebral palsy. Based on an analysis of the available literature, all three preparations have been established to reduce hypertonia in the upper and lower extremities, with some conflicting evidence regarding function. There were no differences in treatment safety, with a low incidence of adverse events which were mostly temporary and mild. Any form of universal conversion ratio between all preparations is not recommended.
\end{abstract}

Key words: botulinum toxin, cerebral palsy

(Neurol Neurochir Pol 2021; 55 (2): 158-164)

\section{Introduction}

Cerebral palsy (CP) has been described as: "a group of permanent disorders of the development of movement and posture causing activity limitations, which are attributed to nonprogressive disturbances in the developing foetal or infant brain" [1].

$\mathrm{CP}$ is the main cause of disability among children and adolescents [2]. The majority of children with $\mathrm{CP}$ are affected by some form of hypertonia, of which spasticity is the most common [3]. Untreated spasticity leads to the development of contractures and bone deformities [4]. Other reasons for treating spasticity include improving mobility, facilitating the use of orthoses, improving posture and hand function, reducing pain from muscle spasms, and easing patient care/hygiene [5].

Over the past three decades, botulinum toxin type-A (BoNT-A) has become established as an important treatment modality for hypertonia in children with CP. After Koman et al. reported the first use of OnaBoNT-A in the treatment of spasticity associated with $\mathrm{CP}$ [6], the results of small-group studies that were published in the early 1990s showed that both
OnaBoNT-A and AboBoNT-A were effective in the treatment of calf muscle spasticity resulting in tiptoeing $[7,8]$. Over the following years, efficacy in the treatment of other muscles such as hamstrings or adductors has been presented $[9,10]$.

The biggest breakthrough in the BoNT-A therapy of children with $\mathrm{CP}$ was the introduction of multi-level injections as part of a multimodal rehabilitation process which includes physiotherapy and orthoses among a range of other treatments. Such an integrated approach brings measurable results and changes the natural course of the disease $[11,12]$. Subsequent years saw a rapid increase in the number of publications. In 2010, the American Academy of Neurology and Child Neurology Society published a Practice Parameter evaluating evidence from 148 studies; 15 studies encompassing the treatment of 573 patients rose to the highest Class 1 level, and five studies rose to the Class 2 level [13]. Since then, a considerable amount of evidence has been published on this subject. Placebo controlled (PC) double blinded (DB) RCTs have shown significant improvements in different measures compared to placebo without major differences between toxin brands (Tab. 1). In 2019, the

Address for correspondence: Marcin Bonikowski, Mazovian Neuropsychiatry Centre, Limited Liability Company, Neuro Rehabilitation Department, Movement Analysis Lab., 05-462 Zagorze, Poland, e-mail: martinbonikowski@gmail.com 
Table 1. Randomised clinical trials (RCT), double blind (DB), single blind (SB), placebo controlled (PC), multicentre (MC), single centre (SC)

\begin{tabular}{|c|c|c|c|c|c|}
\hline References & $\begin{array}{l}\text { Study design/ } \\
\text { /number of } \\
\text { groups/duration } \\
\text { of observation } \\
\text { (weeks)/number } \\
\text { of treatments }\end{array}$ & $\begin{array}{l}\text { Patient characteristics/ } \\
\text { /number of assessed/ } \\
\text { /outcome measures } \\
\text { 1. primary 2. secondary }\end{array}$ & $\begin{array}{l}\text { BoNT-A brand } \\
\text { and dose (U/kg) }\end{array}$ & $\begin{array}{l}\text { Muscles injected/ } \\
\text { injection guide }\end{array}$ & $\begin{array}{c}\text { Efficacy outcomes (only } \\
\text { significant)/adverse } \\
\text { events }\end{array}$ \\
\hline $\begin{array}{l}\text { Koman et al. } \\
1994[8]\end{array}$ & $\begin{array}{l}\mathrm{RCT} ; \mathrm{DB} ; \mathrm{PC}: \mathrm{SC} \\
\mathrm{Ml} / 6 \text { weeks } / 2 / 2 \\
\text { (second after } \\
2 \text { weeks) }\end{array}$ & $\begin{array}{l}n=12 ; \text { PRS, ROM, Biodex } \\
\text { Isokinetic Dynamometry }\end{array}$ & OnaBoNT-A/2-4 & $\begin{array}{l}\text { GST/manual pal- } \\
\text { pation }\end{array}$ & $\begin{array}{l}\text { PRS, ROM, no statistical } \\
\text { analysis/AE-3 pts treated } \\
\text { and } 6 \text { pts placebo arm }\end{array}$ \\
\hline $\begin{array}{l}\text { Sutherland et } \\
\text { al.1999 [14] }\end{array}$ & $\begin{array}{l}\mathrm{RCT} ; \mathrm{DB} ; \mathrm{PC} ; \mathrm{SC} / 2 / 8 \\
\text { weeks } / 2 \text { (second } \\
\text { after } 4 \text { weeks) }\end{array}$ & $\mathrm{n}=19 ; 3 \mathrm{D}, \mathrm{EMG}, \mathrm{ROM}$ & OnaBoNT-A/2-4 & ND & $\begin{array}{l}\text { Ankle kinematics/ROM/ } \\
\text { AE-no }\end{array}$ \\
\hline $\begin{array}{l}\text { Koman et al. } \\
2000[15]\end{array}$ & $\begin{array}{l}\mathrm{RCT} ; \mathrm{DB} ; \mathrm{PC} \text {, } \\
\mathrm{MC} / 2 / 12 \text { weeks } / 2 \\
\text { (second after } 4 \\
\text { weeks) }\end{array}$ & $\begin{array}{l}n=108 ; \\
\text { 1. PRS, } . \text { ROM, AROM, H-reflex, } \\
\text { Blood serum antibodies }\end{array}$ & $\begin{array}{l}\text { OnaBoNT-A/4-8/ } \\
\text { repeated after } 4 \\
\text { weeks }\end{array}$ & $\begin{array}{l}\text { GST/manual pal- } \\
\text { pation }\end{array}$ & $\begin{array}{l}\text { PRS, AROM/AE- } 12 \text { pts } \\
\text { treated and } 3 \text { pts placebo } \\
\text { arm }\end{array}$ \\
\hline $\begin{array}{l}\text { Ubhi et al. } 2000 \\
\text { [16] }\end{array}$ & $\begin{array}{l}\mathrm{RCT} ; \mathrm{DB} ; \mathrm{PC} ; \\
\mathrm{SC} / 2 / 12 \text { weeks/1 }\end{array}$ & $\begin{array}{l}\mathrm{n}=40 \\
1.2 \mathrm{D} 2.2 \mathrm{D}, \mathrm{ROM}, \mathrm{GMFM}\end{array}$ & AboBoNT-A/15-25 & $\begin{array}{l}\text { GST, SOL, HMST, } \\
\text { manual palpation }\end{array}$ & $\begin{array}{l}\text { Ankle kinematics, GMFM } \\
\text { AE- } 6 \text { pts treated and } 1 \text { pt } \\
\text { placebo arm }\end{array}$ \\
\hline $\begin{array}{l}\text { Baker et al. } \\
2002[17]\end{array}$ & $\begin{array}{l}\text { RCT; DB; PC; } \\
\text { MC/4/16 weeks } / 1\end{array}$ & $\begin{array}{l}n=124 \\
\text { 1. MTS 2. ROM, GMFM }\end{array}$ & AboBoNT-A/10-30 & $\begin{array}{l}\text { GSC/manual pal- } \\
\text { pation }\end{array}$ & $\begin{array}{l}\text { ROM, MTS/AE } 123 / 94 \\
\text { pts treated and } 20 / 31 \mathrm{pts} \\
\text { placebo arm, } 24 \% \text { related } \\
\text { to treatment }\end{array}$ \\
\hline $\begin{array}{l}\text { Kanovsky et al. } \\
2004 \text { [18] }\end{array}$ & $\begin{array}{l}\mathrm{RCT} ; \mathrm{DB} ; \mathrm{PC} ; \\
\mathrm{MC} / 2 / 16 \text { weeks } / 1\end{array}$ & $\begin{array}{l}n=52 \\
1 / 2 D ; G M F M\end{array}$ & AboBoNT-A/ 30 & $\begin{array}{l}\text { GSC/manual pal- } \\
\text { pation }\end{array}$ & $\begin{array}{l}\text { Ankle kinematics/ } \\
\text { AE- } 30 / 10 \text { pts treated and } \\
33 / 13 \text { pts placebo arm }\end{array}$ \\
\hline $\begin{array}{l}\text { Ackman et al. } \\
2005[19]\end{array}$ & $\begin{array}{l}\text { RCT; SB; PC; MC/3/ } \\
\text { BTX-A/BTX-A+C/ } \\
\text { PL+C/56/3 }\end{array}$ & $\begin{array}{l}n=34 ; \\
1 / 3 D ; 2 / R O M, M A S \text {, strength }\end{array}$ & OnaBoNT-A/4-8 & GSC/ND & $\begin{array}{l}\text { ROM, MAS, 3D, strength - } \\
\text { only BTX-A + GR/AE-3 pts } \\
\text { treated and } 6 \text { pts placebo } \\
\text { arm }\end{array}$ \\
\hline $\begin{array}{l}\text { Mall et al. } 2000 \\
{[10]}\end{array}$ & $\begin{array}{l}\mathrm{RCT} ; \mathrm{DB} ; \mathrm{PC} ; \\
\mathrm{MC} / 2 / 12 \text { weeks } / 1\end{array}$ & $\begin{array}{l}\mathrm{n}=57 \\
\text { 1. Knee to knee distance } 2 . \\
\text { ROM, MAS, GMFM, GAS }\end{array}$ & AboBoNT-A/30 & ADD, HMST/ND & $\begin{array}{l}\text { Knee to knee distance, } \\
\text { MAS, GAS, AE } 9 \text { pts treated } \\
\text { and } 3 \text { pts placebo arm }\end{array}$ \\
\hline $\begin{array}{l}\text { Bjornson et al. } \\
2007[20]\end{array}$ & $\begin{array}{l}\mathrm{RCT} ; \mathrm{DB} ; \mathrm{PC} ; \\
\mathrm{SC} / 2 / 24 \text { weeks } / 1\end{array}$ & $\begin{array}{l}\mathrm{n}=33 ; \\
\text { 1.Spasticity/GMFM66 /88 } \\
\text { 2.AS, ROM, EMG, E.C.I., } \\
\text { strength, GMFM, GAS, COPM }\end{array}$ & OnaBoNT-A/12 & GST/ES & $\begin{array}{l}\text { ROM/AE - } 6 \text { pts pain at } \\
\text { injection site }\end{array}$ \\
\hline $\begin{array}{l}\text { Moore et al. } \\
2008 \text { [21] }\end{array}$ & $\begin{array}{l}\mathrm{RCT} ; \mathrm{DB} ; \mathrm{PC} ; \mathrm{SC} / 2 / 2 \\
\text { years/every } 3 \\
\text { months if clinically } \\
\text { indicated }\end{array}$ & $\begin{array}{l}n=124 \\
\text { 1. GMFM, PEDI }\end{array}$ & AboBoNT-A/10-30 & $\begin{array}{l}\text { GSC/manual pal- } \\
\text { pation }\end{array}$ & $\begin{array}{l}\text { No differences in long } \\
\text { term follow-up/AE- } 208 \text { in } \\
29 \text { pts treated and } 200 \text { in } \\
27 \text { pts placebo arm }\end{array}$ \\
\hline $\begin{array}{l}\text { Delgado et al. } \\
2016 \text { [22] }\end{array}$ & $\begin{array}{l}\mathrm{RCT} ; \mathrm{DB} ; \mathrm{PC} ; \\
\mathrm{MC} / 3 / 12\end{array}$ & $\begin{array}{l}n=228 \\
1 / M A S ; 2 / P G A, G A S, M T S)\end{array}$ & AboBoNT-A/10-30 & GST+SOL/USG & $\begin{array}{l}\text { MAS, PGA, MTS, GAS, } \\
\text { AE - } 144 \text { pts. } 2 \% \text { treatment } \\
\text { related }\end{array}$ \\
\hline $\begin{array}{l}\text { Corry et al. } \\
1997[23]\end{array}$ & $\begin{array}{l}\mathrm{RCT} ; \mathrm{DB} ; \mathrm{PC} ; \\
\mathrm{SC} / 2 / 12 \text { weeks } / 1\end{array}$ & $\begin{array}{l}\mathrm{n}=14 ; 1 / \mathrm{MAS} ; 2 / \mathrm{ROM}, \mathrm{MTS} \\
\mathrm{G} \& \mathrm{R}\end{array}$ & $\begin{array}{l}\text { OnaBoNT-A/4-7 } \\
\text { AboBoNT-A/8-9 }\end{array}$ & $\begin{array}{l}\text { BB, BR, FCR, FCU, FDS, } \\
\text { FDP, FPL, PT/anatomi- } \\
\text { cal landmarks }\end{array}$ & $\begin{array}{l}\text { MAS, ROM, G\&R } \\
\text { AE-2pts }\end{array}$ \\
\hline $\begin{array}{l}\text { Koman et al. } \\
2013[24]\end{array}$ & $\begin{array}{l}\text { RCT; DB; PC; } \\
\text { MC/2/27 weeks/1 }\end{array}$ & $\mathrm{n}=73 ; 1 /$ UERS, MA, HC, MHC & $\begin{array}{l}\text { OnaBoNT-A/ } \\
1.4-12.5\end{array}$ & $\begin{array}{l}\text { Shoulder, arm, fore- } \\
\text { arm, hand without } \\
\text { spec; anatomical } \\
\text { landmarks, USG }\end{array}$ & $\begin{array}{l}\text { ROM (wrist only), MA } \\
\text { AE-5pts }\end{array}$ \\
\hline $\begin{array}{l}\text { Ferrari et al. } \\
2014 \text { [25] }\end{array}$ & $\begin{array}{l}\text { RCT; DB; PC; } \\
\text { MC/2/24 weeks/1 }\end{array}$ & $\begin{array}{l}\mathrm{n}=27 \mathrm{MAS}, \mathrm{GAS}, \mathrm{AHA}, \text { PEDI, } \\
\mathrm{AK}\end{array}$ & $\begin{array}{l}\text { OnaBoNT-A/total } \\
\text { dose }<300 \mathrm{U}\end{array}$ & $\begin{array}{l}\text { PT, FCU, FCR, ADP, } \\
\text { OPP, BB, PM, FDS, } \\
\text { FDS, SSC/USG }\end{array}$ & $\begin{array}{l}\text { GAS, AHA } \\
\text { AE-1pt }\end{array}$ \\
\hline
\end{tabular}

ES - electrostim; C - serial casting; GAS — Goal Attainment Scaling; GMFM — Gross Motor Function Measure; MAS — Modified Ashworth Scale; PRS — Physicians Rating Scale; ROM — Range of Motion; MTS - Modified Tardieu Scale; 3D - three-dimensional gait analysis; 2D - video gait analysis; PGA — Physician's Global Assessment; G\&R - grasp and release score; UERS - upper extremity rating scale; ND - no data; QUEST — Quality of Upper Extremity Skill Test; PEDI — Paediatric Evaluation of Disability Inventory; AK — ABILHAND-Kids; AE — adverse events; pts — patients 
Cochrane review of BoNT-A treatment of lower limb spasticity in children by Blumetti et al. [26] included 31 randomised controlled trials assessing 1,508 participants. Studies compared BoNT-A in lower limb muscles to usual care or physiotherapy (PT) (14 studies), placebo or sham (12 studies), serial casting (four studies), or orthoses (one study). 20 studies used OnaBoNT-A and eight studies used AboBoNT-A.

The authors concluded that children receiving BoNT-A injections tended to have improved gait pattern, ROM, satisfaction with the outcome of treatment, and muscle tone, compared to their usual programme of care or PT, or a placebo. The quality of the evidence was very low for the comparison of BoNT-A versus usual care or physiotherapy; moderate for the comparison of BoNT-A versus placebo; moderate and low for the comparison of BoNT-A versus plaster casts; and very low for the comparison of BoNT-A versus orthoses. The authors did not mention any differences between different brands of toxins.

In 2020, Farag et al. [27] published a systematic review of RCTs of BoNT-A treatment of upper limb spasticity in children with CP. 15 RCTs with a total of 499 participants were analysed. 12 studies used OnaBoNT-A, and two used OnaBoNT-A and AboBoNT-A. The authors found evidence to support the use of BoNT-A as an adjunctive treatment to other modalities such as regular PT and occupational therapy (OT) with regard to the reduction of spasticity. Evidence to support its use as an adjunctive treatment to improve upper limb function or quality of life was insufficient. Any differences between brands of toxins were not reported.

In 2012, Pin et al. [28] published a systematic review of the efficacy of BoNT-A in non-ambulant children with severe CP: 19 studies were included. Indications for treatment were pain reduction, maintaining hip integrity, achieving functional changes, and goal attainment. A high percentage of participants in the studies showed positive changes. But most of the studies were of weak-to-moderate methodological quality. The authors did not analyse brands of toxins used. BoNT-A is compared to other treatment modalities in most studies, but in clinical practice it is used as a complement to them. For this reason, the evaluation of its effectiveness as an adjunctive therapy seems interesting. In a review based on a 'traffic light' scheme, Novak et al. assessed 247 articles and 398 intervention outcomes [29]. Interventions were classified with recommendations: green indicating "do it", yellow "probably do it", yellow "probably do not do it", and red "clearly do not do it". 14\% (54 /398) of interventions achieved the level of green. Among them were: BoNT-A + OT for UE motor goals achievement (1-3 RCT), BoNT-A for tone reduction (UE + LE) (> 15 RCT), and BoNT + Casting for ROM (contractures) (4-15 RCT). BoNT-A + PT for mobility (4-15 RCT), BoNT-A + PT for tone reduction, BoNT-A for ROM and Prevention of Hip Displacement (1-3 RCT), and BoNT-A + Hip Brace for Prevention of Hip Displacement (1-3 RCT) were rated yellow among 66\% (264/398) of interventions.
From the very beginning of BoNT-A's use in paediatrics, the safety of treatment has been evaluated. The reported RCTs and analyses showed no differences between BoNT-A and placebo for adverse events (AEs). A systematic review of 20 randomised studies of botulinum toxin A, enrolling 882 participants, reported 35 different AEs. [30]. 17 studies used OnaBoNT-A and four studies used AboBoNT-A. According to the authors, botulinum toxin type-A use was related to respiratory tract infection, bronchitis, pharyngytis, asthma, muscle weakness, urinary incontinence, falls, seizures, fever and unspecified pain. The authors concluded that botulinum toxin type-A has a good safety profile during the first months of use. However, the demonstration of a relationship between BoNT treatment and common childhood diseases and other common diseases in the population of children with CP may raise doubts. An interesting single centre report from 356 patients and 1,382 injection sessions indicated the overall rate of AEs for BoNT-A as being 3.3\% for the sessions and $8.7 \%$ for the patients [31]. Both OnaBoNT-A and AboBoNT-A were injected. The data indicated that repeated BoNT-A injections were safe; $\mathrm{AE}$ were described as mild and were not associated with BoNT-A dose or brand. AE reactions were associated with GMFCS level and presence of epilepsy, but were mostly mild even for severely affected patients.

The largest study on the efficacy and safety of AboBoNT-A treatment of children with $\mathrm{CP}$ is the retrospective study by Bakheit et al. [32]. Among 758 patients (1,594 sessions), the AE rate was $7 \%$. However, in the group that received drug doses higher than $1,000 \mathrm{U} /$ session or $30 \mathrm{U} / \mathrm{kg}$ body weight, this percentage was $22 \%$. In a meta-analysis of the safety of OnaBoNT-A, 1,447 treated subjects were compared to a 914-strong control group [33]. The incidence of AE was approximately $25 \%$ in patients treated with OnaBoNT-A, and $15 \%$ in the control group. The authors found a significantly higher incidence only for focal weakness in the treatment group.

Interesting from the point of view of this review are studies in which both OnaBoNT-A and AboBoNT-A were used [9, 23, $34,35]$ and according to the authors preparations were used depending on availability. There were no differences between the preparations in terms of efficacy and safety, but none of the studies compared them directly. Two other papers have described the transition from OnaBoNT-A to AboBoNT-A for economic or administrative reasons $[36,37]$. The authors found no differences in the efficacy or safety of the treatment. Tedroff et al. used a fixed 1:2 conversion ratio of OnaBoNT-A to AboBoNT-A. Dursun et al. based dosing decisions on the child's individual presentation at that time. Carraro et al. [38] analysed the safety profile of IncoBoNT-A compared to OnaBoNT-A (ratio 1:1) in the treatment of lower limb spasticity. The authors found no significant difference in frequency and type of AE. León-Valenzuela et al. looked at treatment safety of IncoBoNT-A with dose increase [39]. 69 children, mean age (SD) 8.3 (3.9) years, received IncoBoNT-A injections up to a maximum total dose of $600 \mathrm{U}, 24 \mathrm{U} / \mathrm{kg}$ body weight. 
191 injections were administered, with a dosing interval of 6.0 (1.7) months. The mean (SD) total IncoBoNT-A dose increased from 191.7 (126.2) U at cycle 1 to 368.0 (170.1) U) at cycle $6.74 \mathrm{AEs}$ (37.5\% of injections) were reported, the most frequent being injection pain (93.2\% of AEs). $36.8 \%$ of participants were classified at GMFCS levels IV and V, without any safety concerns.

In recent years, manufacturer-sponsored, multicentre, international, Phase 3, RCTs have been conducted to assess the efficacy and safety of AboBoNT-A, OnaBoNT-A and IncoBoNT-A in lower and upper limb therapy.

Until this article was published, only the results of the research on AboBoNT-A have been published as full articles; the results of the research on IncoBoNT-A and OnaBoNT-A have only been published as abstracts. In DB RCT and openlabel (OL) extension studies (NCT01249417/ NCT01251380), 241 ambulatory children aged 2-17 with dynamic equinus were randomised to treatment with AboBoNT-A (10 or $15 \mathrm{U} / \mathrm{kg} / \mathrm{leg}$ ) or placebo injected into the gastrocsoleus. All children received AboBoNT-A in the OL phase. In DB RCT, treatment-related AEs (TRAE) were evenly distributed, with the highest rate (9\%) in the placebo group. [22]. Repeated injections of AboBoNT-A in an open label study were generally well tolerated, with the number of patients experiencing TRAE varying from 16 in cycle 1 to 1 in cycle 4 . In both studies, the majority of TRAE were related to injection procedure and injection site pain was the most frequent. Significantly higher decreases of muscle hypertonia and spasticity (MAS, MTS), goal achievement (GAS), and overall global clinical impression (PGA) were demonstrated for the treatment groups [22, 40, 41]. In the double-blind phase, AboBoNT-A significantly improved observational gait scale (OGS) total scores versus placebo at week 4, and continued to improve gait throughout the OL phase [42]. Importantly, a long-term therapeutic effect was demonstrated: $74 \%$ of children treated did not require retreatment before week 16 or later, with $17.7 \%$ of patients not requiring retreatment before week 28 [40]. In DB, a repeat-cycle study (NCT02106351) saw 210 children, mean age (SD) 9y (4y 5mo), receive $2 \mathrm{U} / \mathrm{kg}, 8 \mathrm{U} / \mathrm{kg}$, or $16 \mathrm{U} / \mathrm{kg}$ AboBoNT-A injections into UE alongside a home-exercise therapy programme. All children received $8 \mathrm{U} / \mathrm{kg}$ or $16 \mathrm{U} / \mathrm{kg}$ in cycles 2 to 4 . At week 6 of cycle 1 , children in the $8 \mathrm{U} / \mathrm{kg}$ or $16 \mathrm{U} / \mathrm{kg}$ groups had significantly lower MAS scores versus the $2 \mathrm{U} / \mathrm{kg}$ group. There were no differences in GAS and PGA between groups. Therapeutic benefits were sustained during cycles 2 to 4 . Muscular weakness was the only TRAE reported in at least one child/ /group [43]. In DB RCT (NCT0193411) 241 ambulatory children (aged 2-17) with dynamic equinus were treated with three different doses (16, 12, 4 U/kg BW) of IncoBoNT-A in two subsequent cycles. Overall, improvements in Ashworth Scale (AS) were observed in all IncoBoNT-A treatment groups at week 4 , without statistically significant differences. There were also no significant differences in re-injection time (cycle 2) [44]. From that group, 124 patients entered an open-label extension study (NCT01905683) and, together with 246 newly recruited patients (total 370), received up to four cycles of multilevel injections in LE and combined LE/UE muscles, with doses up to $20 \mathrm{U} / \mathrm{kg}(500 \mathrm{U})$ of IncoBoNT-A.

The results showed a consistent improvement in plantar flexor hypertonia (AS) over long-term treatment [45]. The results of a similar to the previous PC DB RCT with OL extension study (NCT02002884), but focusing on UE spasticity, were recently published [46]. In the MP, 350 patients aged 7.3 (4.4) years received 8, 6, 2 U/kg BW of IncoBoNT-A into upper limb, with additional lower-limb injections up to $20 \mathrm{U} / \mathrm{kg}$ BW followed by three further injection cycles in OL extension study. In the DB, AS scores for the UE main clinical pattern improved significantly from baseline to week 4 , with a significantly greater improvement in the $8-\mathrm{U} / \mathrm{kg}$ versus the $2-\mathrm{U} / \mathrm{kg}$ dose group. Improvements were observed in all treated $\mathrm{UE}$ and LE clinical patterns and across all OL cycles.

In analysis of pooled safety data from the three abovementioned LE and UE IncoBoNT-A studies, the authors reported $2 \%$ of patients experienced AEs possibly related to the treatment [47]. In DB PC RCT (NCT01603628), OnaBoNT-A $8 \mathrm{U} / \mathrm{kg} / \mathrm{leg}, 4 \mathrm{U} / \mathrm{kg} / \mathrm{leg}$, or placebo was injected into ankle plantar flexors of 384 patients OnaBoNT-A significantly decreased spasticity at weeks 4 and 6; it decreased by $1.1(8 \mathrm{U} / \mathrm{kg})$ and 1.0 (4 U/kg); OnaBoNT-A $8 \mathrm{U} / \mathrm{kg}$ significantly improved Clinical Global Impression (CGI) and improved measures of gait versus placebo [48]. Both OnaBoNT-A groups significantly improved active and passive GAS. Moreover, the authors presented gait improvement measured by Edinburgh Visual Gait (EVG) score in the subset of patients. Dose $8 \mathrm{U} / \mathrm{kg}$ demonstrated statistical significance vs placebo at week 8 in the total score and select individual items (associated with foot stance and swing) [49].

As in previous studies, AboBoNT-A presented a good safety profile. Rates of patients reporting $\geq 1$ AEs were similar across treatment groups. In DB PC RCT study (NCT01603602), 235 children (mean age 7.9 years; range 2-16) were injected with OnaBoNT-A $6 \mathrm{U} / \mathrm{kg} / \mathrm{side}, 3 \mathrm{U} / \mathrm{kg} /$ side, or placebo into UE muscles; patients also received occupational therapy. Toxin groups demonstrated significant reductions of hypertonia and spasticity (MAS and MTS) compared to placebo, but did not differ significantly in mean CGI. Only the $6 \mathrm{U} / \mathrm{kg}$ group demonstrated significant improvement in GAS passive goals at week 12 but not in active goals. OnaBoNT-A was well tolerated in both treatment groups, with no safety concerns [50].

To conclude, data from multicentre studies showing the efficacy and safety of BoNT treatment in almost 2,000 children with different hypertonia distributions, functional and health statuses could provide the final proof.

Moreover, the authors presented a sustained effect of treatment not only in reducing hypertonia (MAS) but also in improving body function and activity. Interestingly, the dose ratio for higher dose groups in LE studies was 1.9/1/1 for 
Abo/Inco/Ona BoNT-A respectively. The differences in duration of response need further analysis.

\section{Summary}

Based on the presented studies, we conclude that BoNT-A is safe in spasticity treatment in the majority of children with CP.

In clinical practice, BoNT-A treatment should always be addressed to the patient for whom the reduction of hypertonia has the potential to provide a meaningful benefit in active function, hip integrity, comfort, or care. It is obligatory to use BoNT-A in conjunction with other treatment modalities such as OT, PT, orthotics or casting.

There are no major differences between Abo, Inco and OnaBoNT-A both in PC DB RCT and observational studies. The low number of comparative studies does not provide evidence on exchange ratios.

From the clinician's point of view, different preparations of BoNT-A should be considered as distinct medications. All should be used while respecting individual country's relavent SPCs.

\section{References}

1. Rosenbaum P, Paneth N, Leviton A, et al. A report: the definition and classification of cerebral palsy April 2006. Dev Med Child Neurol Suppl. 2007; 109: 8-14, indexed in Pubmed: 17370477.

2. Oskoui M, Coutinho F, Dykeman J, et al. An update on the prevalence of cerebral palsy: a systematic review and meta-analysis. Dev Med Child Neurol. 2013; 55(6): 509-519, doi: 10.1111/dmcn.12080, indexed in Pubmed: 23346889.

3. Sanger TD, Delgado MR, Gaebler-Spira D, et al. Task Force on Childhood Motor Disorders. Classification and definition of disorders causing hypertonia in childhood. Pediatrics. 2003; 111(1): e89-e97, doi: 10.1542/peds.111.1.e89, indexed in Pubmed: 12509602.

4. Molenaers G, Van Campenhout A, Fagard K, et al. The use of botulinum toxin $A$ in children with cerebral palsy, with a focus on the lower limb. J Child Orthop. 2010; 4(3): 183-195, doi: 10.1007/s11832010-0246-x, indexed in Pubmed: 21629371.

5. Strobl W, Theologis $\mathrm{T}$, Brunner R, et al. Best clinical practice in botulinum toxin treatment for children with cerebral palsy. Toxins (Basel). 2015; 7(5): 1629-1648, doi: 10.3390/toxins7051629, indexed in Pubmed: 25969944.

6. Koman LA, Mooney JF, Smith B, et al. Management of cerebral palsy with botulinum-A toxin: preliminary investigation. J Pediatr Orthop. 1993; 13(4): 489-495, doi: 10.1097/01241398-19930700000013, indexed in Pubmed: 8370782.

7. Cosgrove AP, Corry IS, Graham HK. Botulinum toxin in the management of the lower limb in cerebral palsy. Dev Med Child Neurol. 1994; 36(5): 386-396, doi: 10.1111/j.1469-8749.1994.tb11864.x, indexed in Pubmed: 8168657.

8. Koman LA, Mooney JF, Smith BP, et al. Management of spasticity in cerebral palsy with botulinum-A toxin: report of a preliminary, randomized, double-blind trial. J Pediatr Orthop. 1994; 14(3): 299-303, doi: 10.1097/01241398-199405000-00005, indexed in Pubmed: 8006158.
9. Corry IS, Cosgrove AP, Duffy CM, et al. Botulinum toxin A in hamstring spasticity. Gait Posture. 1999; 10(3): 206-210, doi: 10.1016/s09666362(99)00037-5, indexed in Pubmed: 10567752.

10. Mall V, Heinen F, Kirschner J, et al. Evaluation of botulinum toxin A therapy in children with adductor spasm by gross motor function measure. J Child Neurol. 2000; 15(4): 214-217, doi: 10.1177/088307380001500402, indexed in Pubmed: 10805185.

11. Molenaers G, Desloovere K, Fabry G, et al. The effects of quantitative gait assessment and botulinum toxin a on musculoskeletal surgery in children with cerebral palsy. J Bone Joint Surg Am. 2006; 88(1): 161 170, doi: 10.2106/JBJS.C.01497, indexed in Pubmed: 16391261.

12. Scholtes VA, Dallmeijer AJ, Knol DL, et al. The combined effect of lower-limb multilevel botulinum toxin type a and comprehensive rehabilitation on mobility in children with cerebral palsy: a randomized clinical trial. Arch Phys Med Rehabil. 2006; 87(12): 1551-1558, doi: 10.1016/j.apmr.2006.08.342, indexed in Pubmed: 17141633.

13. Delgado MR, Hirtz D, Aisen M, et al. Quality Standards Subcommittee of the American Academy of Neurology and the Practice Committee of the Child Neurology Society. Practice parameter: pharmacologic treatment of spasticity in children and adolescents with cerebral palsy (an evidence-based review): report of the Quality Standards Subcommittee of the American Academy of Neurology and the Practice Committee of the Child Neurology Society. Neurology. 2010; 74(4): 336-343, doi: 10.1212/WNL.0b013e3181cbcd2f, indexed in Pubmed: 20101040.

14. Sutherland DH, Kaufman KR, Wyatt MP, et al. Double-blind study of botulinum A toxin injections into the gastrocnemius muscle in patients with cerebral palsy. Gait Posture. 1999; 10(1): 1-9, doi: 10.1016/ s0966-6362(99)00012-0, indexed in Pubmed: 10469936.

15. Koman LA, Mooney JF, Smith BP, et al. Botulinum toxin type A neuromuscular blockade in the treatment of lower extremity spasticity in cerebral palsy: a randomized, double-blind, placebo-controlled trial. BOTOX Study Group. J Pediatr Orthop. 2000; 20(1): 108-115, indexed in Pubmed: 10641699.

16. Ubhi T, Bhakta BB, Ives HL, et al. Randomised double blind placebo controlled trial of the effect of botulinum toxin on walking in cerebral palsy. Arch Dis Child. 2000; 83(6): 481-487, doi: 10.1136/ adc.83.6.481, indexed in Pubmed: 11087280.

17. Baker R, Jasinski M, Maciag-Tymecka I, et al. Botulinum toxin treatment of spasticity in diplegic cerebral palsy: a randomized, double-blind, placebo-controlled, dose-ranging study. Dev Med Child Neurol. 2002; 44(10): 666-675, doi: 10.1017/s0012162201002730, indexed in Pubmed: 12418791.

18. Kaňovský P, Bares M, Severa S, et al. Functional benefit of botulinum toxin (Dysport $\circledast$ ) in the treatment of dynamic equinus cerebral palsy spasticity: a prospective, multicentre, double-blind, placebo-controlled study. Ceska a Slovenska Neurologie a Neurochirurgie. 2004; 67: 16-23.

19. Ackman JD, Russman BS, Thomas SS, et al. Shriners Hospitals BTX-A Study Group. Comparing botulinum toxin A with casting for treatment of dynamic equinus in children with cerebral palsy. Dev Med Child Neurol. 2005; 47(9): 620-627, indexed in Pubmed: 16138670.

20. Bjornson K, Hays R, Graubert C, et al. Botulinum toxin for spasticity in children with cerebral palsy: a comprehensive evaluation. Pediatrics. 2007; 120(1): 49-58, doi: 10.1542/peds.2007-0016, indexed in Pubmed: 17606561.

21. Moore AP, Ade-Hall RA, Smith CT, et al. Two-year placebo-controlled trial of botulinum toxin A for leg spasticity in cerebral palsy. Neurology. 2008; 71(2): 122-128, doi: 10.1212/01.wnl.0000316801.74683. c0, indexed in Pubmed: 18606966. 
22. Delgado MR, Tilton A, Russman B, et al. AbobotulinumtoxinA for Equinus Foot Deformity in Cerebral Palsy: A Randomized Controlled Trial. Pediatrics. 2016; 137(2): e20152830, doi: 10.1542/peds.20152830, indexed in Pubmed: 26812925.

23. Corry IS, Cosgrove AP, Walsh EG, et al. Botulinum toxin A in the hemiplegic upper limb: a double-blind trial. Dev Med Child Neurol. 1997; 39(3): 185-193, doi: 10.1111/j.1469-8749.1997.tb07408.x, indexed in Pubmed: 9112968.

24. Koman LA, Smith BP, Williams R, et al. Upper extremity spasticity in children with cerebral palsy: a randomized, double-blind, placebo-controlled study of the short-term outcomes of treatment with botulinum A toxin. J Hand Surg Am. 2013; 38(3): 435-46.e1, doi: 10.1016/j. jhsa.2012.12.019, indexed in Pubmed: 23428186.

25. Ferrari A, Maoret AR, Muzzini S, et al. A randomized trial of upper limb botulimun toxin versus placebo injection, combined with physiotherapy, in children with hemiplegia. Res Dev Disabil. 2014; 35(10): 2505-2513, doi: 10.1016/j.ridd.2014.06.001, indexed in Pubmed: 24995688.

26. Blumetti FC, Belloti JC, Tamaoki MJs, et al. Botulinum toxin type A in the treatment of lower limb spasticity in children with cerebral palsy. Cochrane Database Syst Rev. 2019 [Epub ahead of print]; 10: CD001408, doi: 10.1002/14651858.CD001408.pub2, indexed in Pubmed: 31591703.

27. Farag SM, Mohammed MO, El-Sobky TA, et al. Botulinum Toxin A Injection in Treatment of Upper Limb Spasticity in Children with Cerebral Palsy: A Systematic Review of Randomized Controlled Trials. JBJS Rev. 2020; 8(3): e0119, doi: 10.2106/JBJS.RVW.19.00119, indexed in Pubmed: 32224633.

28. Pin TW, Elmasry J, Lewis J. Efficacy of botulinum toxin A in children with cerebral palsy in Gross Motor Function Classification System levels IV and V: a systematic review. Dev Med Child Neurol. 2013; 55(4): 304-313, doi: 10.1111/j.1469-8749.2012.04438.x, indexed in Pubmed: 23095013.

29. Novak I, Morgan C, Fahey M, et al. State of the Evidence Traffic Lights 2019: Systematic Review of Interventions for Preventing and Treating Children with Cerebral Palsy. Curr Neurol Neurosci Rep. 2020; 20(2): 3, doi: 10.1007/s11910-020-1022-z, indexed in Pubmed: 32086598.

30. Albavera-Hernández C, Rodríguez JM, Idrovo AJ. Safety of botulinum toxin type A among children with spasticity secondary to cerebral palsy: a systematic review of randomized clinical trials. Clin Rehabil. 2009; 23(5): 394-407, doi: 10.1177/0269215508099860, indexed in Pubmed: 19389744.

31. Papavasiliou AS, Nikaina I, Foska K, et al. Safety of botulinum toxin A in children and adolescents with cerebral palsy in a pragmatic setting. Toxins (Basel). 2013; 5(3): 524-536, doi: 10.3390/toxins5030524, indexed in Pubmed: 23482250.

32. Bakheit AM, Severa S, Cosgrove A, et al. Safety profile and efficacy of botulinum toxin A (Dysport) in children with muscle spasticity. Dev Med Child Neurol. 2001; 43(4): 234-238, doi: 10.1017/ s0012162201000445, indexed in Pubmed: 11305399.

33. Naumann M, Albanese A, Heinen F, et al. Safety and efficacy of botulinum toxin type A following long-term use. Eur J Neurol. 2006; 13 Suppl 4: 35-40, doi: 10.1111/j.1468-1331.2006.01652.x, indexed in Pubmed: 17112348.

34. Corry IS, Cosgrove AP, Duffy CM, et al. Botulinum toxin A compared with stretching casts in the treatment of spastic equinus: a randomised prospective trial. J Pediatr Orthop. 1998; 18(3): 304-311, indexed in Pubmed: 9600553.
35. Fehlings $D$, Rang $M$, Glazier J, et al. An evaluation of botulinum-A toxin injections to improve upper extremity function in children with hemiplegic cerebral palsy. J Pediatr. 2000; 137(3): 331-337, doi: 10.1067/mpd.2000.108393, indexed in Pubmed: 10969256.

36. Tedroff K, Befrits G, Tedroff CJ, et al. To switch from Botox to Dysport in children with $\mathrm{CP}$, a real world, dose conversion, cost-effectiveness study. Eur J Paediatr Neurol. 2018; 22(3): 412-418, doi: 10.1016/j. ejpn.2018.01.023, indexed in Pubmed: 29452742.

37. Dursun N, Akarsu M, Gokbel T, et al. Switching from onabotulinumtoxin-A to abobotulinumtoxin-A in children with cerebral palsy treated for spasticity: A retrospective safety and efficacy evaluation. J Rehabil Med. 2019; 51(5): 390-394, doi: 10.2340/16501977-2550, indexed in Pubmed: 30931483.

38. Carraro E, Trevisi E, Martinuzzi A. Safety profile of incobotulinum toxin A $[$ Xeomin $(囚)]$ in gastrocnemious muscles injections in children with cerebral palsy: Randomized double-blind clinical trial. Eur J Paediatr Neurol. 2016; 20(4): 532-537, doi: 10.1016/j.ejpn.2016.04.008, indexed in Pubmed: 27177451.

39. León-Valenzuela A, Palacios JS, Del Pino Algarrada R. IncobotulinumtoxinA for the treatment of spasticity in children with cerebral palsy - a retrospective case series focusing on dosing and tolerability. BMC Neurol. 2020; 20(1): 126, doi: 10.1186/s12883-020-01702-7, indexed in Pubmed: 32268880.

40. Delgado MR, Bonikowski M, Carranza J, et al. Safety and Efficacy of Repeat Open-Label AbobotulinumtoxinA Treatment in Pediatric Cerebral Palsy. J Child Neurol. 2017; 32(13): 1058-1064, doi: 10.1177/0883073817729918, indexed in Pubmed: 28914131.

41. Tilton A, Russman B, Aydin R, et al. AbobotulinumtoxinA (Dysport) Improves Function According to Goal Attainment in Children With Dynamic Equinus Due to Cerebral Palsy. J Child Neurol. 2017; 32(5): 482-487, doi: 10.1177/0883073816686910, indexed in Pubmed: 28068857.

42. Dursun N, Bonikowski M, Dabrowski E, et al. Efficacy of Repeat AbobotulinumtoxinA (Dysport $\circledast$ ) Injections in Improving Gait in Children with Spastic Cerebral Palsy. Dev Neurorehabil. 2020; 23(6): 368374, doi: 10.1080/17518423.2019.1687602, indexed in Pubmed: 31691605.

43. Delgado MR, Tilton A, Carranza-Del Río J, et al. Dysport in PUL study group. Efficacy and safety of abobotulinumtoxinA for upper limb spasticity in children with cerebral palsy: a randomized repeat-treatment study. Dev Med Child Neurol. 2021; 63(5): 592-600, doi: 10.1111/ dmcn.14733, indexed in Pubmed: 33206382.

44. Heinen F, Kaňovský P, Schroeder A, et al. Efficacy and safety of incobotulinumtoxinA for lower-limb spasticity in children and adolescents with cerebral palsy. Toxicon. 2018; 156: S44, doi: 10.1016/j.toxicon.2018.11.109.

45. Kaňovský $P$, Heinen F, Schroeder S, et al. Long-term safety and efficacy of incobotulinumtoxinA for lower- or combined upper- and lower-limb spasticity in children and adolescents with cerebral palsy. Toxicon. 2018; 156: S56, doi: 10.1016/j.toxicon.2018.11.135.

46. Dabrowski E, Chambers H, Gaebler-Spira D, et al. Efficacy and safety of incobotulinumtoxinA for upper- or combined upper- and lower-limb spasticity in children and adolescents with cerebral palsy: Results of the Phase 3 XARA study. Toxicon. 2021; 190: S14-S15, doi: 10.1016/j.toxicon.2020.11.369.

47. Banach M, Kaňovský P, Schroeder AS, et al. eister T, L, . Safety of incobotulinumtoxinA in multipattern treatment of upper- and lower-limb spasticity in children/adolescents with cerebral palsy: Pooled analysis of 3 large phase 3 studies, Toxicon 2021; Vol 190. ; 2021 (Supp. 1): S7. 
48. Kim H, Meilahn J, et al. Efficacy and safety of onabotulinumtoxina for the treatment of pediatric lower limb spasticity: primary results. Developmental Medicine \& Child Neurology. 2018; 60: 33-33, doi: 10.1111/dmcn.49_14017.

49. Kim H, Racette B, Dunn C, et al. Lower limb injections of onabotulinumtoxinA: Improvement in gait and treatment goal achievement in pediatric patients with cerebral palsy. Toxicon. 2021; 190: S40-S41, doi: 10.1016/j.toxicon.2020.11.425.

50. F2 efficacy and safety of onabotulinumtoxina for the treatment of pediatric upper limb spasticity: primary results. Developmental Medicine \& Child Neurology. 2018; 60: 33-34, doi: 10.1111/ dmcn.50_14017. 